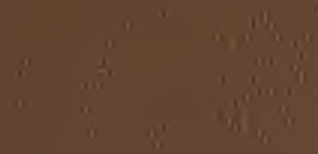

n

0

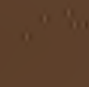

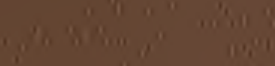
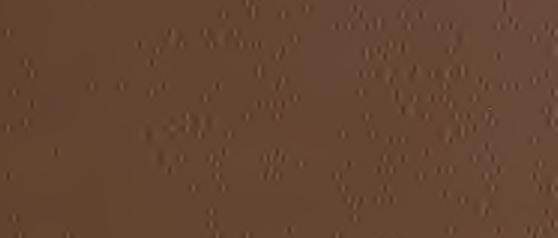

$y_{0} 0$
110:

Bonsine (1) 10 "Yig, Q. $x$ mon' initiy $\lim _{11} x$

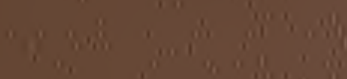
i) in 111

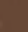

ing in 
RYOF MELUBRARYOF.

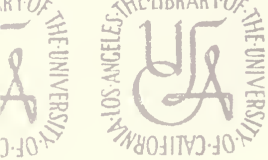

FORN,

, ant-7ty

(ERSS/s,

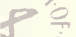

8

$001 \times 1)^{2}$

VERS/rs.

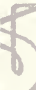

Soly $\mathrm{x}^{2}$

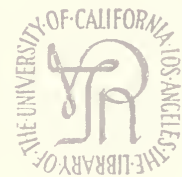

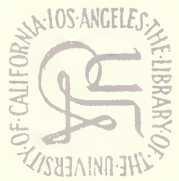

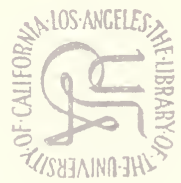

ARYOF.

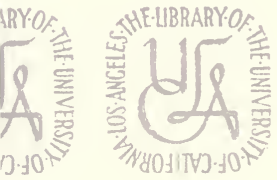

$\mathrm{FOR}_{\mathrm{N}, \mathrm{K}}$

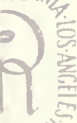
$87 \cdot 3 \mathrm{H}^{2}$

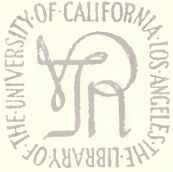

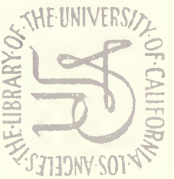

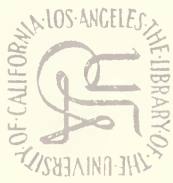

S.THE.UNIVERS/\%).
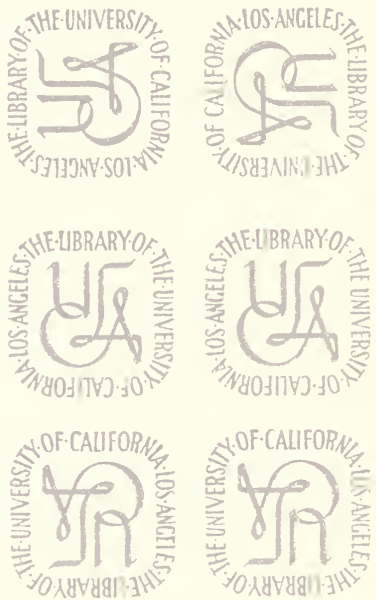

S.XHEUNIVERSIT,
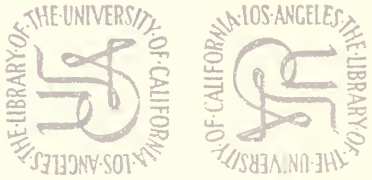

S.HEVUNIVERSIT,
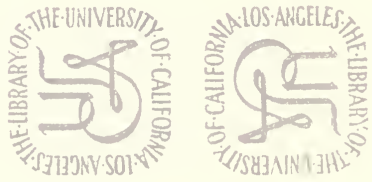

AHE.LIBRARYO,
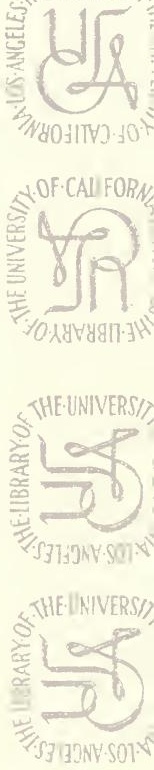

ME.LIBRARYO

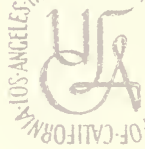

N.OF.CALIFORA

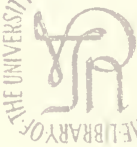

VERSI/2, W.LOS.ANCELES.

S.THEUNIVERS/,

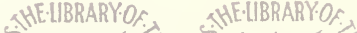





\title{
A
}

$\begin{array}{lllllllllllllllll} & \mathrm{S} & \mathrm{Y} & \mathrm{N} & \mathrm{O} & \mathrm{P} & \mathrm{S} & \mathrm{I} & \mathrm{S}\end{array}$

O F A

COURSE OF LECTURES

\author{
O N
}

\section{Anatomy and Physiology.}

y BUSICK HARWOOD, M. D. F. R. S. E S. A.

PROFESSOR OF ANATOMY

IN THE UNIVERSITY OF CAMBRIDGE.

THIRDEDITION.

PRINTED BY F. HODSON,

FOR J. AND J. MERRILI, CAMBRIDGE;

T. CADELL IN THE STRAND, B. WHITE AND SON,

ELEET-STREET, AND G.AND T. WILKIE,

ST. PAUL'S CHURCH-YARD, LOND ON,

M DCC XCIr. 


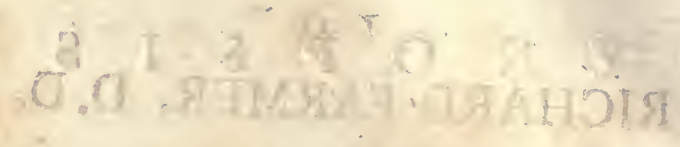

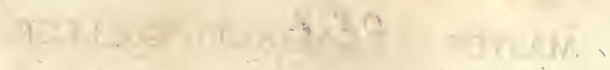

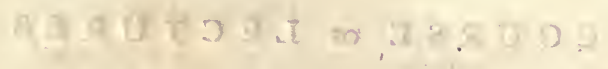

$$
\begin{aligned}
& 196.8 \\
& \text { Whomatawn's bus motanA }
\end{aligned}
$$

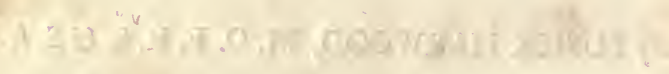

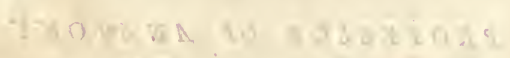

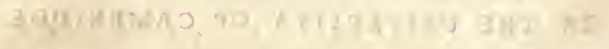

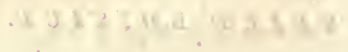

10

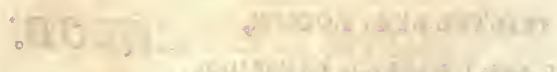

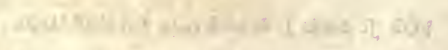

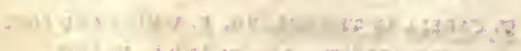

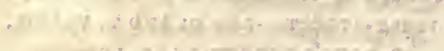

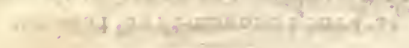

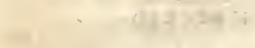




\title{
T $\mathrm{O}$
}

\section{RICHARD FARMER, D.D.}

MASTER oF EMMANUEL COLLEGE

\author{
A N D
}

PRINCIPAL LIBRARIAN

IN THE UNIVERSITY OF CAMBRIDGE,

THE FOLLOWING

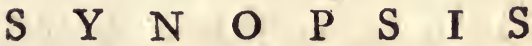

O F A

C OURSE of LE C T URES

O N

Anatomy and Phyfiology,

IS MOST RESPECTFULLY INSCRIBED,

$$
\text { B } \mathbf{Y}
$$

HIS MOST OBEDIENT HUMMBLE SERVANT,

\section{BUSICK HARWOOD:}

Exmaneri. College;

xf: Feb. I792. 
$-1$

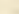

$\cdot$

$-2+2+20$

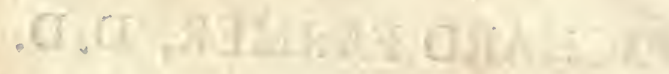

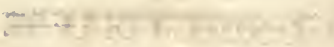

$$
\begin{aligned}
& \text { and }
\end{aligned}
$$

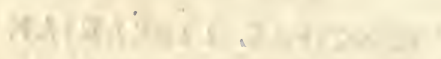

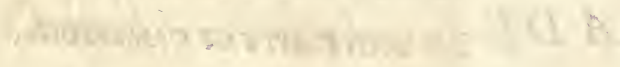

$$
\begin{aligned}
& \text { Gemprays त }
\end{aligned}
$$

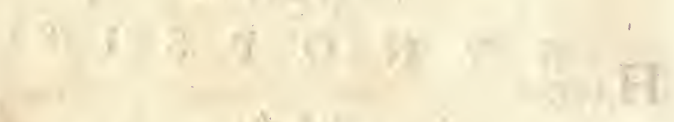

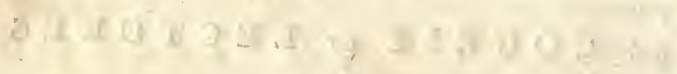

$$
\begin{aligned}
& \text { is }
\end{aligned}
$$

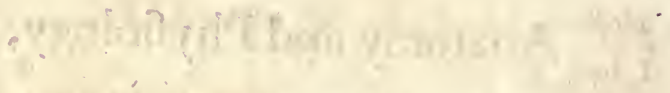

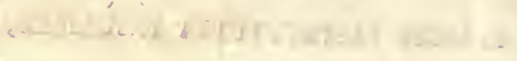

$$
\begin{aligned}
& 24
\end{aligned}
$$

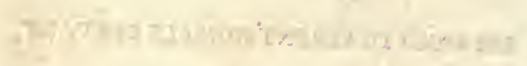

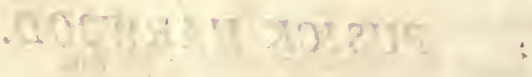

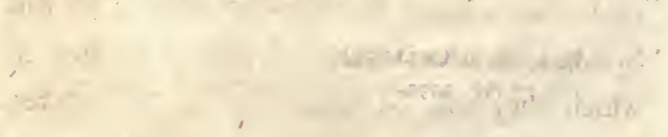




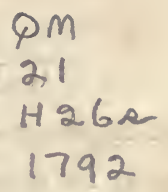

\section{A DVERTISEMENT.}

\section{$\mathrm{H}_{\text {AVING found that the Compendium Ana- }}$} томісUм made ufe of by my predeceffor, was infufficient to anfwer all the purpofes of the more enlarged plan, which I have ventured to adopt in the delivery of anatomical lectures; I have been led to attempt the compofition of a Syllabus, which I hope will convey a more perfect idea of the fubjects I intend to enlarge upon in the enfuing courfe.

With regard to the order, in which I have chofen to arrange the different articles of this Syllabus, I have adhered as nearly to that in which they will be treated of at the lectures, 


\section{( vi )}

as the nature of the undertaking would admit. And to remedy the inconvenience, which might arife from any occafional breach in this order, I have avoided the divifion of it into feparate. lectures, and have prefixed numbers to each article, by which means they may be referred to at pleafure. The number of articles has alfo been reduced into as fmall a compafs as poffible, by omitting the enumeration of the Bones and Mufcles, a catalogue of which will be found at the end of the Syllabus.

Befides the more immediate purpofe for which the following pages were defigned, I am not without hopes that an attempt (which as far as I know is the firft,) to collect and arrange the principal facts, and difcoveries in Anatomy, may be of ufe to other Teachers of the art, who may poffibly think it worth while to extend and improve the plan which I now offer to the Public.

After the Anatomy of the human body is completed, it is likewife my intention to give 


\section{( vii )}

fome feptrate lectures on the ftructure of Animals. And in the divifion of the fubject, all thofe Analogies which affift us in explaining the ftructure and ufes of the Animal CEconomy, will be particularly pointed out.

The articles which compofe this part of the Syllabus, are comprifed under the general head of Comparative Anatomy. 


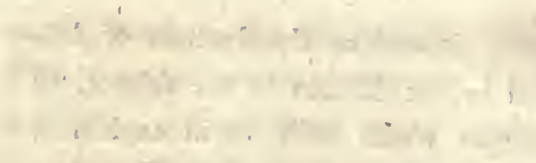

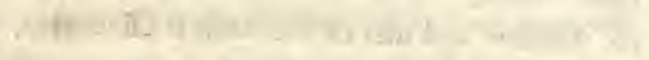

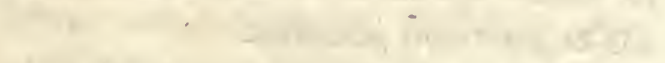

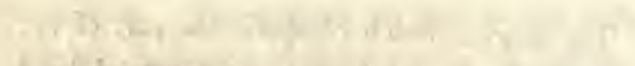

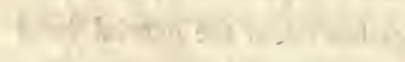








\section{N T R O D U C TION.}

\section{Hiftory of Anatomy.}

1. $\mathrm{R}$ ISE, progrefs, and prefent R ftate of the fcience.

Of its general utility.

2. Of the various kinds of preparations made ufe of, in inveftigating the more obfcure parts of the human frame.

3. Explanation of the inftruments, and the manner of ufing them, for the purpofe of preparing, and preferving, the different parts of an animal body.

4. Neceffary cautions concerning the ufe of anatomical preparations. 


$$
\text { (2) }
$$

5. Explication of the general terms of Anatomy.

of the Nature, and Properties of the

$$
\text { B L O O D. }
$$

6. Recent blood appears like an homogeneous fluid.

Of the means employed to difcover its compofition.

Of. the Separate Parts of the Blood. Serum.

7. The properties and ufe of this fluid.

Saline particles cortained in it.

\section{Crassamentum.}

8. Compoled of two parts. Separation of thefe parts by walhing in water. 


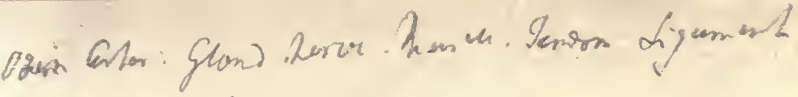
dymplinat opple. 





\section{(3)}

Particular Examination of each.

Red Globules.

9. Suppofed caufe of their red colour. Various opinions concerning their nature and formation.

Microfcopic obfervations, \&c.

10. Theories of Lewenhoec, Hewfon and others.

\section{Coagulable Lymph.}

11. Its peculiar properties.

Is the caufe of the fpontaneous feparation of the blood into two parts.

12. Theory of the formation, and regeneration of parts, by means of the Coagulable Lymph.

13. Morbid appearances of the blood:

14. Difference between arterial and venous blood.

$$
\text { A } 2 \text { 15. Prieftly's }
$$




\section{(4)}

15. Priefty's doctrine, and experiments.

16. Human blood compared with that of animals.

\section{Hiftory of Transfufion.}

17. Method of performing the operation.

18. Effects of Transfufion on various animals.

General Divifions of the Human Body. 19. Hippocrates's divifion into Continentes, Content \& \& impetum FACIENTES.

Other divifions of the antients.

Of A N I A L FIBRES. 20. Their Aructure.

Infinite divifibility of an animal fibre. 






\section{( 5 )}

Various kinds of fibres.

Their gradual increafe and elongation.

21. Obfervations on the preternatural growth of giants.

22. Of wounds in general.

23. Cicatrices how formed.

Of Membranes.

24. General idea of their ftructure and various ufe.

Their different degrees of fenfibility, in a healthy, and in a morbid ftate.

\section{Of $\mathrm{B} \mathrm{O} \mathrm{N} \mathrm{E} \mathrm{S.}$}

25. The beginning and progrefs of Offication.

Of the variety of this procefs in the flat, cylindric, and fpherical bones.

26. General ftructure of bones. Cancelli how formed. 


\section{(6)}

Remarks on the growth of bones. 27. Chemical analyfis of bone. 28. Of the varieties in the fhape and fubftance of bones.

Of the comparative ftrength of bones.

29. Of their nerves and blood-veffels. Exquifite fenfibility of bones in fome difeafes.

Evident effect of diet on the bones.

Of the bones of animals fed on Madder.

30. External conformation of the bones.
Apophyfes, Epiphyfes, \&c.
Of the Periosteum.

31. Manner in which it is connected to the bones.

Texture and ufes of this membrane. 






\section{$(7)$}

\section{Of the Marrow.}

32. Its nature and ufe. Increafe of its fenfibility in difeafe. 33. Of the pori medullares. Remarks on the curious diftribution of thefe pores.

34. Difeafes of the bones.

35. General effects of the Lues Venerea upon them.

Exhibition of the different appearances produced in them by this difeafe.

$3^{6}$. Remarks concerning the treatment of frmple and compound fractures. Callus how formed, \&c. 37. Ufe of the bones in general. of Cartilages.

$3^{8}$. Their fituation and manifold ufes. 39. Difference of their Atructure. 10. Are claffed under three general heads. 


\section{(8)}

1. Of the Perichondrium, and its
ufe.

Of Ligaments.

42. Their variety.

43. Of the ftructure, and ufe of ligaments in general.

44. Of capfular ligaments in particular.

45. Practical remarks concerning the treatment of wounds of the ligaments, and cartilages.

\section{Of ARTICULATION.}

46. Of the feveral fpecies of articulation, admitting different degrees of motion.

47. Explanation of each particular fpecies.

48. General account of the fynovial glands, and of the fluid fecreted by them, for the lubrication of the joints.

49. Practical 






\section{( 9 )}

49. Practical remarks on the different kinds of luxations, and the modes of reducing them.

50. Of Anchylofis.

\section{SK E L E T O N.}

$5^{1}$. Of the different kinds of Skeletons, and methods of preparing them.

52. General divifion of the Skeleton. * Bones of the Head, Trunk, and Extremities, feparately confidered.
Of the Cranium.

53. Natural figure, fize, and unequal thicknefs of the fkull.

54. Of the tables of the cranium.

Of the diploë and its ufes.

55. The fkull compofed of feveral bones.

B $56 . *$ Particular

* See a Catalogue of the bones of the Human Skeleton, at the end of this Syllabus. 


\section{(10)}

56. * Particular defcription of the Sutures, by which thefe bones are connected with each other.

57. Advantages arifing from this mode of connexion.

Sutures often obliterated.

Of their accidental varieties.

Of the Offa Triquetra.

58. Obfervations on the original conformation of the fkull.

View of the external bafis of the fkull.

59. Of the various proceffes obfervable in this part of the cranium. Their names, fituations, and ufes.

6o. Obfervations on the general, and particular ufes of each procefs.

61. General view of the internal cavity of the cranium.

\section{Of}

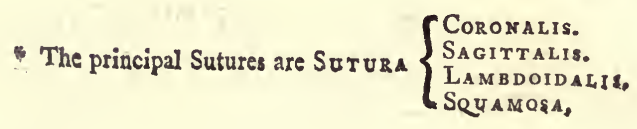








\section{(11)}

62. Of the various impreffions, pits, and furrows in this cavity.

Marks of the longitudinal, and lateral finus's, \&c.

63. Divifion of its internal bafis. 64. Defcription and ufe of the ProcefJes, \&c. in the cavity of the fkull.

65. Remarks on the attachment of the Dura Mater.

66. Of the different foramina, for the paffage of blood-veffels and nerves.

Obfervations on the ufe of each. $67 .{ }^{2}$ Remarks on the entrance of the carotid and vertebral arteries into the fkull.

68. Of fractures of the fkull.

Of concuffions.

Operation of the trepan, when neceffary and how performed. Cautions to the furgeon in performing this operation.

$$
\text { B } 2 \text { 69. Defcrip- }
$$




\section{(12)}

69. Defcription of the feparate bones of the cranium.

70. Obfervations on the form, ftructure, and particular ufe of each.

\section{of the bones of the face.}

71. Of their connexion with the proper bones of the fkull.

72: A particular defcription of each of thefe bones.

73. Of their general, and particular ufes.

74. Of the formation and ufe of the Lachrymal Duct.

75. Remarks on the manner of performing the operation for the Fifula Lachrymalis.

76. Of Caries, and other difeafes of the bones of the face.

77. Of the lower Jaw.

Of its Articulation: 






\section{(13)}

Of the alveolar proceffes.

Of the abforption of thefe proceffes in old age.

78. Of the teeth in general.

${ }^{b}$ Of the ftructure and form of the $\therefore$ different claffes of teeth.

Of their enamel, and its ufes.

79. Obervations on the paffage of the nerves into the teeth.

Of the original formation of the teeth, \&c.

80. Of their difeafes.

Remarks on the ufual method of drawing teeth.

Of the S P I N E.

81. Of the vertebræ in general.

Of their ftructure.

82. Of the proceffies of the vertebræ and their feparate ufes.

83. Of the large canal for the tranfmiffion of the fpiral marrow. 


\section{(14)}

\section{Of the lateral holes for the paf- fage of the nerves.}

\section{of the Vertebrae of the Neck.}

84. Of the Atlas and Epistropheus.' Obfervations on their peculiar form, and articulation.

85. Of the perforations of the cervical vertebræ, for the paffage of the vertebral artery.

\section{of the Dorfal Vertebrae.}

86. Of their fubftance, fize, \&c.

87. Of their articulation with the ribs.

Of the Lumbar Vertebra.

88. Of their fituation and ftrength. 89 Of the peculiarities of the vertebræ of the back and loins.

90. Of the ligaments connecting the vertebræ.

91. Of their intervening cartilages: 






\section{( 15$)$}

92: Of the incurvations of the fine: 93. Of its mechanifm and ufes. 94. Deformities of the fpine.

Their caufes, and methods of cure.

Of the PELVIS.

\section{of the Os Sacrum.}

95. Of the falfe vertebræ and holes for the paffage of nerves.

96. Of the Os Coccygis.

Its Atructure and ufe.

of the Os Innominatum.

97. Compofed of the Ilium, Ifchium, and Pubis.

98. Thefe bones feparately confi. dered.

99. Acetabulum how formed.

100. Of the Symphyfis Pubis.

101. Remarks on the Aructure, and different capacities, of the Pelvis, in the male and female Skeleton.' 


$$
\text { ( } 16)
$$

102. Deformities of the Pelvis confsdered ás the caufe of difficult births.

\section{Of the THORAX.}

103. Of the Ribs in general,

Their divifion into true and falle

Q ribs.

Of their form, fituation, \&c.

104. Of the cartilages of the ribs.

Obfervations on the ufe of thefe cartilages.

105. Of the deformities and difeafes of the ribs.

Remarks on the treatment, and confequences of fractured ribs.

of the Sternum.

106. Of the feparate bones of the fternum.

Of the xyphoid cartilage. 107. Remarks 






\section{(17)}

107. Remarks on the general fructure, and ufe of the thorax.

108. Obfervations on the motion of the ribs, and fternum, in refpiration.

\section{Of the Upper Extremity.}

109. Of the Scapula.

Its ftructure, fhape, proceffes, $\& c$.

Of its articulation with the clavicle, and with the humerus.

110. Of the Clavicle.

Its fituation, ftructure and ufes.

111. Of the Humerus.

Structure, proceffes, and articu. lation of this bone.

Of the extent of its motion.

112. Of the treatment of fractures, and luxations, of the fhoulder, and arm.

113. Of the RAdIUS and ULNA,

$$
\text { C The }
$$




\section{( 18$)$}

The fructure, \&c. of thefe bones, feparately examined.

Of their articulation with each other, with the humerus, and with the carpal bones.

114. Of their particular ules, and the variety of their motions.

115. Of the interoffeus ligament, and its ufes.

116. Of the CARPUS.

Of the eight bones of the carpus, their names, ftructure, and different Thapes.

Of their fituation, and cornexion with each other.

Of their articulation with the bones of the fore-arm, and metacarpus.

117. Obfervation on their motion and ufes.

118. Of the Metacarpus.

The bones of which it is compofed, feparately confidered. 






\section{(19)}

\section{Of their articulations, \&c.}

119. Of the Bones of the Fingers and Thumb.

Of their ftructure, articulations, \&c.

120. Remarks on the number, fituation, and ufes, of the Offa Seffamoidea.

121. General Obfervations on the mechanifm, and ufes, of the bones of the upper extremity.

Of the Lower Extremity.

122. Of the OS FEMORIS.

Its form and fituation in general.

Particular defcription of the ftructure, and ufes, of the trochanters, condyles, and other remarkable parts of this bone.

Of its articulation with the os innominatum.

$$
\mathrm{C}_{2} \text { 123. Obfer- }
$$




\section{( 20$)$}

123. Obfervations on the motions of this joint.

124. Of luxations, fractures, \&c. of the thigh bone, and methods of treating them.

125. Of the Tibia and Fibula.

General defcription of their fructure and fhape.

Separate examination of all the parts of thefe bones.

Of their connexion with each other.

Of the articulation of the tibia, with the os femoris.

126. Of the femilunar cartilages, crucial ligaments, \&c.

127. Of the Petella, and its ufes.

128. Of luxations and fractures of the patella, and of the bones of the leg.

129. Of the Tarsus. 




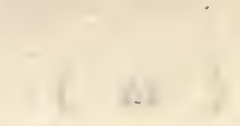

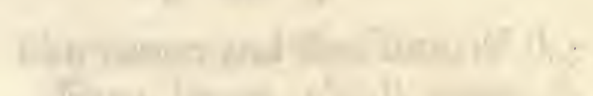

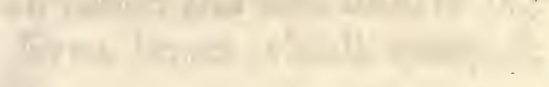

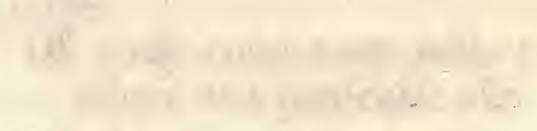

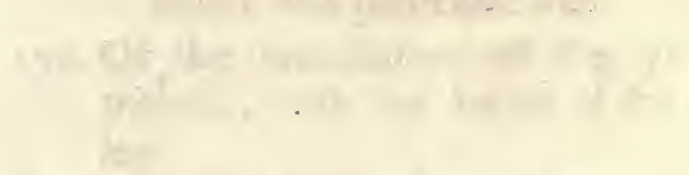

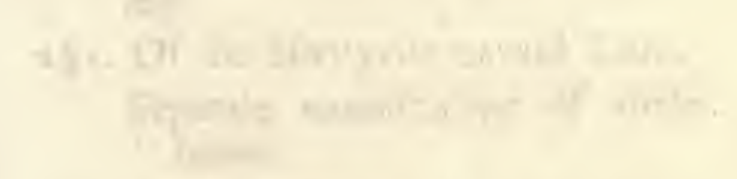

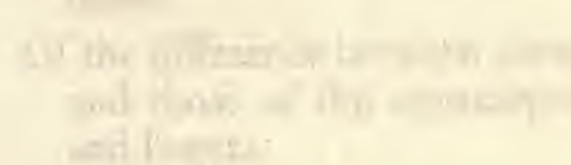

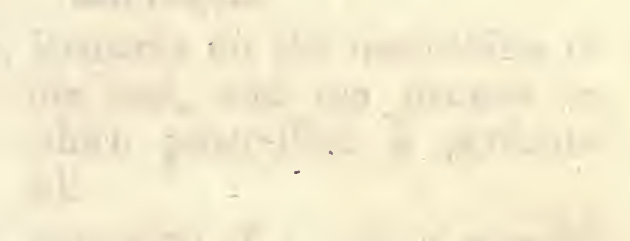





\section{(21)}

The names and ftructure, of the feven bones which compofe it.

Of their connexion with each other, and particular ufes.

130. Of the articulation of the aftragulus, with the bones of the leg.

131. Of the Metatursus and Toes. Separate examination of thefe bones.

Of the difference between them, and thofe of the metacarpus, and fingers.

132. Remarks on the mechanifm of the foot, and the manner in which progreffion is performed.

133. Skeleton of a Fotus examined, and compared with that of the adult fubject.

134. Remarks on its ftriking peculiarities, with regard to the number, thape, 


$$
\text { (22) }
$$

Thape, connexion, and ufes of the bones.

135. Obfervations on the peculiar advantages of the cartilaginous appendages affixed to the bones of a fotus. 




$(23)$

of $M U S C I E S$.

136. F the general fructure, and various attachments, of mufcles.

137. Of fimple, and compound mufcles.

138. Of the names of mufcles derived from their infertion, connexion, form, fituation, ufe, \&c.

139. Mufcles voluntary, and involuntary.

140. Of the phænomena of mufcular action.

141. Hypothefes concerning the immediate caufe of mufcular motion.

142. Tendons how formed.

Of their connexions, and ufes. 


\section{( 24$)$}

143. Aponeurofes.

Their Aructure, and ufes.

* Mufcles of the Abdomen.

144. A particular defcription of their Atructure, and mode of action.

Of their manifold ufe.

Great importance of the action of thefe mufcles, to the animal œconomy.

145. Of Poupart's ligament.

146. ${ }^{\text {'Particular defcription, and ufe }}$ of the abdominal rings.

147. Remarks on the defcent of the teftis.

148. Practical remarks on the different fpecies of Hernice.

149. Obfervations on the manner of performing the operation for Bubonocele.

$$
\text { 150. Of }
$$

* See a Lift of all the Mufcles at the end. 






\section{( 25$)$}

150. Of the treatment of wounds of the abdomen.

Mufcles of the Upper Extremity.

151. Of the mufcles which move the fcapula on the trunk.

152. Of thofe which move the os humeri on the fcapula.

153. Of thofe which move the bones of the fore-arm on the os humeri.

154. Of thofe which move the radius upon the ulna.

155. Of thofe which move the carpus on the fore-arm.

156. Mufcles of the metacarpus and the fingers.

157. Of the general and particular ufes of the mufcles of the upper extremity.

Mufcles of the Lower Extremity.

158. Of the mufcles which move the thigh upon the pelvis.

$$
\text { D 159. Of }
$$




\section{$(26)$}

159. Of thofe which move the bones of the leg, upon the os femoris.

160. Of thofe which move the tarfus on the leg.

161. Mufcles which move the metatarfus, and the toes.

162. Remarks on the ftructure of each of the above mufcles.

Of their ufes.

Mufcles which move the Head on the Trunk.'

263. Situation, ftructure, and ufe of each of thefe mufcles.

Mufcles of the Neck, Back, and Loins.

164. Their ftructure and fituation. Of their general ufes.

165. Of the Phyfology of the Mufcles: 






\section{(27)}

OF the Contents of the

of the Pleura.

166. Its fituation and attachments.

Of the Atructure, and ufes of the pleura.

167. Of the mediafinum, and its ufes.

168. Pathological remarks on the difeafes of the pleura.

Of the hydrops pectoris.

of the Thymus.

169. Different ftates of this gland in the adult fubject, and in the fœtus.

Opinions concerning its ufe.

of the Pericardium.

270. Its ftructure, \&c.

Of the fluid contained in it.

$\mathrm{D}_{2}$ 


\section{(28)}

Of the ufe of the pericardium.

Of the HEART.

171. Of the fituation of the heart. 'Of its form, and general fructure:

Remarks on the difpofition of its mufcular fibres.

172. Divifion of the heart, into auricles, and ventricles.

Of the fepta between the auricles. and ventricles.

Of the foramen ovale.

Obfervations on its being fometimes found pervious in the adult fubject.

of the Right Auricle.

173. Its form, fubftance, and fituation.

Of the opening of the two vence cavce into it. 






\section{(29)}

Of its communication with the right ventricle.

\section{Of the Right Ventricle.}

174. Its particular flructure, fituation, and capacity.

175. The columnce carnece how formed. Their particular ufes explained.

176. Of the valvulce tricuppidales, placed between the right ventricle and auricle.

Their Aructure and ufe.

177. Of the communication of the right ventricle with the pulmonary artery.

Of the valvulce femilunares.

Their ufe, \&c.

of the Left Auricle.

178. Its Aructure, \&c.

Of the entrance of the pulmonary veins into it.

179. Of its communication with the left ventricle. 


\section{$(30)$}

\section{of the Left Ventricle.}

180. Its fubftance, fituation, \&c.

181. Of the valvulce mitrales, placed between this ventricle, and its correfponding auricle.

Of the office of thefe valves, and their manner of acting.

182. Of the communication of the left ventricle with the AORTA. Valves of the aorta.

183. Of the coronary veins and arteries.

184: Remarks on the different capacities, and ftrength of the two ventricles.

185. Obfervations on the involuntary action of the heart.

186. Of the ufe of the heart in general.

187. Of polypi, aneurifm, and other difeafes of the heart, and its veffels. 




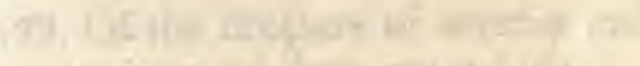

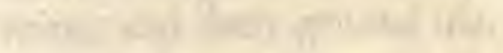

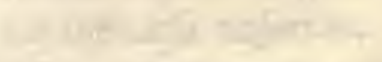

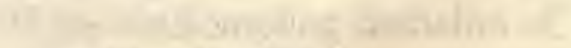

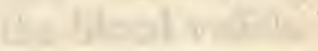

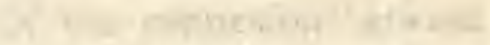

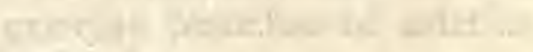
tons ats an

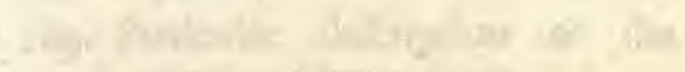

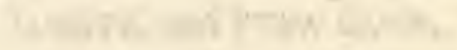

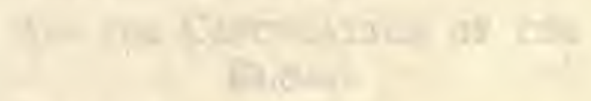

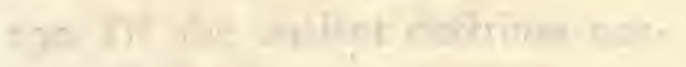

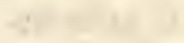

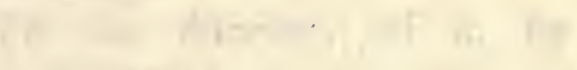

. nn

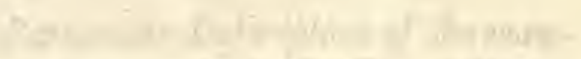

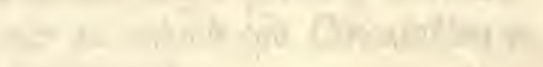

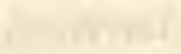

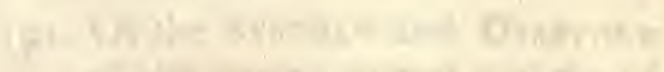

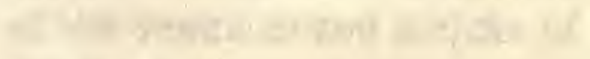

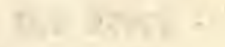

$\therefore$ 



\section{$\left(3^{1}\right)$}

188. Of the ftructure of arteries and veins, and their general ufe.

Of the vafa vaforum.

Of the anaftomofing branches of the blood veffels.

Of the connexion between the extreme branches of arteries and veins.

189. Particular defcription of the AORTA and VENA CAVA.

${ }^{\text {fOF }}$ The Circulation of the BLOOD:

190: Of the ancient doctrines con: cerning it.

Of the difcovery of it, by Harvey.

Particular Defcription of the manner in which the Circulation is performed.

191. Of the Systole and Diastole of the ventricles and auricles of the heart. 


\section{$(32)$}

Of their alternate action.

192. Of the paffage of the blood from the right ventricle to the lungs, by the pulmonary artery.

193. Of its return from the lungs to the left fide of the heart, by the pulmonary vein.

194. Of its exit from the left ventricle, and diftribution throughout the whole body, by the aorta and its branches.

195. Of its return to the right auricle of the heart, by the vena cava.

196. Experimental proofs of the reality of this mode of circulation.

197. Remarks on the quantity of blood, and the velocity with which it circulates in a healthy ftate.

198. Of the valves in the veins, their fituation and ufe.

199. Of the fyflole and diaftole of the arteries.

200. $\mathrm{Ob}=$ 






\section{( 33 )}

200. Obfervations on the different kinds of pulfes, in various difeafes.

sof the L U N G S.

201. Their fituation, and figure.

Their general Aructure, and divifion into lobes.

202. Of the BronchIA, or air veffels.'

Their particular ftructure.

Of their ramifications, and the termination of them in the veficula bronchiales.

203. Of the bronchial arteries and veins.

204. Of the Pulmonary Artery and Vein.

Diftribution of thefe veffels throughout the fubftance of the lungs. 


\section{(34)}

\section{Of their peculiar office.}

205. Of the bronchial glands, and their ufe.

206. Of the trachea, or afpera are teria.

Its ftructure, fituation, and ufe,

\section{${ }^{\natural}$ Of RESPIRA TION.}

of the Diaphragm, and Mufcles. employed in Refpiration.

07. Situation, figure, and attachments of the diaphragm.

Of its crura, and centrum tendinofum.

Of the perforations of the diaphragm for the paffage of the afophagus and vena cava.

208. Remarks on the alternate contraction and relaxation, of this important mufcle.

Hypothefes concerning the caufe of this phœnomenon. 






\section{( 35$)$}

20g. Of the fituation, and office of the intercoftal mufcles.

2io: Of the manner in which refpi ration is performed.

Of expiration and injpiration.

Effects of thefe oppofite actions on the pulmonary veffels.

211. Of the primary ufes of refpira tion:

212. Of the changes produced in the blood; in its paffage through the lungs:

Various opinions of authors on this fubject.

Prieftly's theory and experiments.

213. Of the fecondary ures of the organs of refpiration.

214. Obfervations on the caufe of hickuping, and other fpafmodic affections of the diaphragm.

$$
E_{2} 215 \text {. Of }
$$




\section{$\left(3^{6}\right)$}

215. Of peripneumony, afthma, phthi. fis pulmonalis, and other difeafes ... of the lungs.

216: Of fuffocation.

Remarks on the methods, made ufe of, for the recovery of drowned perfons.

217. General remarks on the peculiarities of the circulation in a fœtus.

of the general diftribution of the Blood-Vefels throughout the body.

218. Of the courfe of the principal arteries and veins.

Of their names, origin, and refpective ufes.

219. The peculiarities of each pointed out, and the caufes of them inveltigated. 




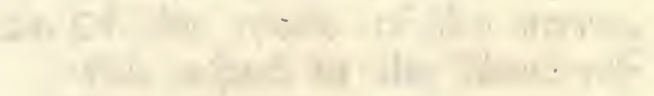

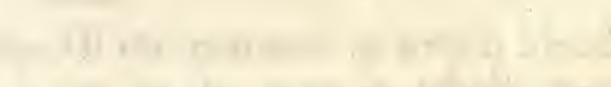

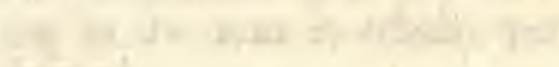
tritsing

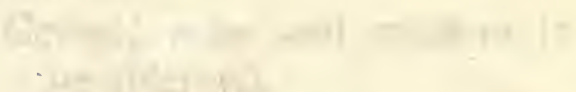

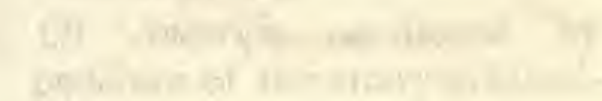

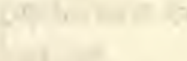





\section{( 37 )}

220. Practical remarks on the treat ment of Popliteal Aneurifm.

221. Of Phlebotomy.

Of the arteries, and veins of the arm, in particular.

Their fituation, feparately, and relatively confidered.

222. Of the courfe of the nerves, with refpect to the blood-veffels.

223. Of the manner in which bleeding in the arm is ufually performed.

General rules and cautions to be obferved.

224. Of Aneurifm occafioned by puncture of the artery in blood. letting.

Reflections on other dangerous confequences of unfkilful venælection.

225. ARtERIOTOMY, how performed, and when neceffary. 


\section{$\left(3^{8}\right)$}

Of the BRA I

Of the Meninges of the Brain.

226. Of the Dura Mater.

Its ftructure and attachments.

227. Of the proceffes of the durd mater and their ufes.

Of the longitudinal, and lateral finus's, Torcular Herophili, \&c.

228. Of the Tunica ARachnoideav

229. Of the Pia Mater.

Its Aructure and ufes.

$230 .{ }^{k}$ Of the circulation of the blood in the brain.

\section{General Divifion of the Brain.}

231. Of the Cerebrum.

Divifion of this part into hemifpheres and lobes.

232. Of the cortical fubftance.

$$
\text { 233. OF }
$$








\section{( 39$)$}

233. Of the medullary fubftance.

234. Of the corpus callofum, fornis, \&c.

235. Of the corpora friata, thalami nervorum opticorum, \&c.

236. Of the tubercula quadrigemina, and pineal gland.

237. Of the four ventricles of the brain, and their communication with each other.

238. Of the infundibulum, pituitary gland, and other remarkable parts of the brain.

of the Cerebellum and Medulla Oblongata.

239. Of their fituation and ftructure.

Of their connexion with each other, and with the cerebrum.

240. Of their peculiarities.

241. Conjectures concerning the ufes of the feveral parts of the brain.

$$
\text { 242, Of }
$$




\section{( 40$)$}

242. Of the ten pair of nerves which pafs out of the ENCEPHALON.

243. A particular defcription of each, and general account of their diftribution, and ufes.

244. Various hypothefes concerning the ufes, and functions of the brain, and nerves in general.

An account of the principal experiments which have been made on this fubject.

of the Spinal Marrow.

245. Its exit from the brain and paffage through the vertebral canal.

246 . Of the nerves arifing from the fpinal marrow, and the diftribution of them throughout the body,

247. Of pains in the head.

248. Of apoplexy, palfy, \&c.

249. Of nervous diforders in general. 






\section{$\checkmark\left(4^{1}\right)$}

\section{Of $\mathrm{GLA} \mathrm{N} \mathrm{D} \mathrm{S.}$}

250. Their divifion into fimple, and compound.

251. Of their excretory ducts.

Difpute between Ruysch and MALPIGHI concerning the ftructure of glands.

252. Of glandular fecretion, and the opinions of various authors on that fubject.

Of morbid fecretions.

253. Opinions concerning the doctrine of tranfudation.

254. Of Schirrus, Cancer, and other difeafes of the glands.

of the Salival Glands.

255. Of the fituation, and office, of the parotid, maxillary, and fublingual glands.

$$
\text { F }
$$




\section{$\left(4^{2}\right)$}

25 . Of their excretory ducts, and the entrance of them into the mouth.

257. Difagreeable confequences of wounds in thefe parts.

258. Of the nature and ufe of the faliva.

of the Mouth in general.

259. Of the lips and palate.

260. Of the glandula lenticulares.

261. Of the os hyoides, and tongue.

262. Of the papillæ of the tongue, and the fenfe of tafting.

263. Of the velum pendulum palati, and uvula.

Confequence of their deftruction by the Lues venerea, and other difeafes.

264. Of the pharynx and cefophagus. Their fituation, flructure, action, and ufes. 






\section{( 43$)$}

265. Of the mufcles employed in maftication, deglutition, and formation of the voice.

Of their feparate ufes, and mode of action.

\section{of the Oefophagus.}

266. Phønomena attending the parfage of the aliment, from the mouth to the ftomach.

267. Of angina or quinfy.

268. Of the LARYNX, and the cartilages which compofe it.

Of the glottis and epiglottis.

Their ftructure, and peculiar ufes.

269. Remarks on the general effects produced by the offification of thefe parts:

$270{ }^{\mathrm{m}} \mathrm{Of}$ the formation of articulate founds.

$$
\text { F } 2
$$




\section{$(44)$}

\section{Of the A B D O M E N.}

271. Of the external form, and regions of the abdomen.

272. Of its internal cavity.

273. Of the peritoncum.

Its ftructure, proceffes, extenfbility, and ufes.

274. Practical obfervations on the caufes; and cure of afcites, and

-ituss other difeafes of the abdomen.

\section{Of the Abdominal Vifcera.}

275. Of the ftomach.

Its fructure, fize, and natural fituation.

Of the coats of the Atomach, and their ufes.

Of the action of the ftomach.

Of the nerves, and blood veffels of the ftomach. 






\section{$(45)$}

\section{Of the cardia and pylorus.}

276. Remarks on the entrance and exit of the food, by thefe orifices.

\section{Of DIGESTION.}

277. Examination of the principal hypothefes which have been formed to explain the nature of this procefs.

Objections to each of thefe.

278. Of the difcoveries lately made on this fubject.

279. ${ }^{\mathrm{n}}$ Of the fuccus gaftricus.

Examination into the nature and properties of this fluid in men and other animals.

280. Experiments of REAUMUR, SPALlanzani and others. 1.883

281. Why the ftomach itfelf is not acted upon by the folvent power of the fuccus gaftricus. 


\section{( $\left.4^{6}\right)$}

282. Of hunger and thirf.

283. Of diet in general.

-284. Of fubftances which promote, or retard digeftion.

Remarks on the pernicious effects of exceflive drinking.

285 . Of the effects of various kinds of poifons taken into the ftomach.

286. Of cardialgia, indigeftion, and other difeafes of this organ.

287. Of the caufes and effects of vomiting.

Remarks on the ufe of emetics in general.

\section{Of the PANCREAS.}

288. Its fructure, fituation, \&c.

Of its excretory duct, and the entrance of it into the duodenum. 






\section{(47)}

289. Of the nature and properties of the pancreatic juice.

${ }^{\circ}$ Of the SPLEEN.

29o. Its ftructure, and fituation.

Of the blood veffels and nerves of the fpleen.

291. Conjectures concerning its ufe. Theories of Hews son and others.

Of animals who have been deprived of this organ.

292. Of the difeafes of the fpleen, and pancreas.

POf the OMENTUM.

293. Its figure, fituation, and ftructure.

Of its blood veffels.

Of the fat contained in the cells . of the omentum. 


\section{Gimpara $\left(4^{8}\right)$}

294. Of the ufe of the omentum.

\section{Of the LIVER.}

295. Form, fituation, and general ftructure of this vifcus.

Of the capfula gliffoni, and external covering of the liver.

Of its nerves and blood veffels.

296. Of the vena portarum.

Its origin, diftribution, and extraordinary office.

297. Of the branches of the cava returning the blood from the liver.

298. Of the hepatic artery.

Obfervations concerning its ufe.

299. Of the pori bilarii.

300. Their origin, and the termination of them in the Hepatic Duct.

301. Of the Gall Bladder.

Its form, fituation, and office. . 302. General 






\section{( 49$)$}

302. ${ }^{9}$ General obfervations concerning thofe animals which have no gall bladder.

3०3. Of the Cyfic Duct.

Its union with the hepatic duct, forming the ductus communis choledochis.

304. Entrance of the ductus communis into the duodenum.

305. Of the ufe of the liver.

306. Of the difference between the cyftic and hepatic biles.

307. Examination into the nature, and ufes of each.

308. Obfervations on the mixture of the bile and pancreatic juice with the imperfect chyle.

309. General account of Chylification. 310. Of the difeafes of the liver.

Of calculi in the gall bladder, \&c.

$$
\text { G } \quad 311 . \mathrm{Of}
$$




\section{( $\left.5^{\circ}\right)$}

311. Of the caufes, fymptoms, and cure of the jaundice.

Of the INTESTINES in general.

312. Divifion of the inteftines into large and fmall.

Of their general fructure, fituation and length.

Of the coats of the inteltines.

Of the fuccus intefinalis.

313. Of the periftaltic motion of the inteltines.

$3^{1} 4$. Of the operation of cathartic medicines, \&c.

315. General defcription of the Mefentery.

Of the Duodenum.

316. Its connexion with the ftomach, \&c.

317. Entrance of the ductus communis, and ductus pancreaticus into it. 






\section{(51)}

Of the valvula conniventes, their fructure and ufe.

Of the Jejunum and Ileum.

318. Their fituation, extent, \&c.

Remarks on the decreale of the valvulæ conniventes in the ileum.

319. Of the entrance of this inteltine into the Colon.

Of the valve of the colon.

Mechanifm and ufe of this valve. Obfervations on the fatal confequences of difeafe in this part.

rof the Corcum.

320 . Its figure, fituation, and fuppoled ufes.

* Of the variety of its Thape and fize in different animals.

321. Of the Appendicula vermiformis coci.

\section{G 2 \\ Con-}

* See comp. anat. 


\section{$(52)$}

- Conjectures concerning its ufe.

\section{Of the Colon.}

322. Defcription of the courfe and circumvolutions of this inteftine.

Of its ligamentary bands and other peculiarities.

Of the Rectum.

323. Its fructure and fituation.

Of the rugat formed by the internal coat of the rectum.

324. Of the Jphincter and levatores ani. 325. Of the glandular lacuna of the large inteftines.

326. Remarks on the difference of the ftructure and ules of the large and fmall inteftines.

327. Of difeafes and wounds of the inteftines.

328. General obfervations on the ufe of clysters. 






\section{( 53 )}

Particular defcription of the Mefentery. 329. Its mode of connexion with the inteltines.

Of the blood veffels, nerves, \&c. of the mefentery and inteftines.

Difribution and ufe of thefe veffels.

\section{Of the Lacteal Vesseis.}

330. Of the firnt difcovery of them by Afellius.

Of the general fructure of the lacteals and lymphatics.

Defcription and ufe of their numerous valves.

331. Of the ampullulae of the lacteals. Demonftration of the lacteals on the inteftines of an animal recently killed.

332. Of their paffage to the thoracic duct. 


\section{( 54$)$}

333. Of the Receptaculum Chyli. 334. Of the Thoracic Duct.

Of the ftructure and fituation of this duct.

Of its termination in the angle between the jugular and fubclavian veins on the left fide. Ufe of this duct.

335. Remarks upon its paffage, and the manner in which the chyle and lymph are propelled through it.

336. Obfervations on the manner in which animals are nourifhed.

'Of the Lymphatics.

337. General hiftory of the abforbent fyftem.

Difcovery of this fyftem in birds, fifhes, and amphibia.

Remarks on the importance of this difcovery. 






\section{( 55 )}

338 . Of the origin of the lymphatics. Their univerfality, \&c:

Of their termination in the thoracic duct.

339. Modus operandi of thefe veffels. Antient opinions concerning abforption by the meferaic veins. Refutation of this doctrine by the experiments of HUNTER and others.

The abforbent powers of thefe veffels, how promoted, \&c.

\section{Of Lymphatic Glands.}

340. Their number, names, fize, and fituation in different parts of the body.

Their ftructure explained.

Of the manner in which the lymphatic veffels are connected with them.

Of the fluid fecreted by them. 


\section{to extan ben $(56)$}

\section{Ufes attributed to them.}

341. Of difeafes of the lymphatic glands ariling from the ablorption of venereal matter, \&c.

342. Of Scrophula.

343. Of the abforption of morbid matter from abfceffes, ulcers, \&c.

344. Practical remarks on the treatment of hydropic complaints in general.

345 . Of the methods of difcovering and injecting the lymphatic veffels.

\section{Of the 'K I D NE'Y'S.}

346 . Of the fituation, and general ftructure of the kidneys.

Of their nerves and blood veffels.

347. Of the cortical, and medullary fubftances of the kidneys.

Of the papillo and their orifices. 






\section{( 57$)$}

"Of the infundibula and pelvis of the kidneys.

348. Remarks on the quantity of blood fent to the kidneys.

349. Fotal peculiarities of the kidneys.

Of the ufe of the kidneys.

350. Of the URETERS.

Their fructure, office, and courfe.

Of their entrance into the bladder.

351. Of the Glandulat Renales.

\section{"Of the BLADDER.}

352. Its fituation, ftructure, and ufe.

353. Evacuation of the urine, how performed.

Of the mufcles employed in this office.

354. Analyfis of urine. 


\section{( $\left.5^{8}\right)$}

355. Remarks on the different ap. pearances of this fluid, in various difeafes.

356. Of Calculi in the kidneys, and the fymptoms attending their paffage to the bladder.

357. Of Nephrotomy.

358. Of ulcers and other difeafes of the kidneys.

359. Of Calculi in the urinary bladder.

360. Analyfis of calculi.

361. Experiments of HALES, and others.

362. Nature and properties of one fpecies inveftigated by SCHEELE.

363. A different fpecies difcovered.

${ }_{3} 64$. Obfervations on the various kinds of folvents made ufe of, for the removal of the ftone.

365. Of Lithotomy, and the methods of performing that operation.

366. Of 






\section{( 59$)$}

366. Of Diabetes, Dy fury, fuppreffion of urine, \&c.

"Of the Male Organs of Generation.

367 . Of the Scrotum.

Its fructure and ufes.

Of the TESTES.

368: Coats of the teftis.

of its general ftructure.

369 . Of the fpermatic artery and vein,

370. Of the tubuli teftis.

The Epidydimis how formed, \&c.

371. Of the ufe of the teftes, and feparation of the femen.

372. Of the properties of the femen, and its agency in the generation of animals.

373. Theories, and experiments of LEWENHOEC and others.

$$
\mathrm{H}_{2} 374 . \mathrm{Of}
$$




\section{(6o)}

374. Of Hydrocele.

375. Of Hernia humoralis, and other difeafes of the tefticles.

376. Of the Vafa deferentia.

377. Remarks on the fructure, and paffage of the fpermatic cord.

378. Obfervations concerning eunuchs.

379. Of the Veficula feminales.

Their texture, fituation, \&c.

Their ufe difputed by

J. Hunter.

Obfervations concerning them.

380. Of the Corpora cavernofa Penis.

Of their cellular ftructure, \&c.

381. Of the Urethra.

Of the corpus fpongiofum urethræ.

Of the bulb of the urethra.

Of the membranous portion of the urethra. 






\section{(6i)}

382. Of the fituation, fructure, and office of the Proftate Gland.

383. Of Cowper's glands.

384. Lacunæ of the urethra, \&c.

385. Of the Glans Penis and Præputium.

386. Of the blood veffels, nerves, and lymphatics of thefe parts.

387. Of the mufcles called Erectores, and Acceleratores.

388. Of the feparate, and combined ufes of the above-mentioned parts.

$3^{889}$. Of ftrictures, and other difeafes of the urethra.

Of the introduction of the catheter.

390. Obfervations on the ufe of Bougies.

391. Of GONORRHœA.

Its fymptoms, and effects.

392. Ob- 


\section{(62)}

392. Obfervations on the ufe of mercury in this difeafe.

393. Of the Lues Venerea.

394. Of the attack and progrefs of this difeafe.

395. Of its local and conftitutional effects.

396. Of the treatment of the lues venerea in its different ftages.

Confequences of neglect or ignorance in the attempts to cure this difeafe.

397. Of mercurial preparations in general.

398. Of the effects of mercury on the conftitution.

*Of the Female Organs of Generation.

399. Of the external parts.

Of the Clitoris, Hymen, and carunculce myrtiformies.

400. Of the Urethra. 






\section{( 63 )}

Its fituation, and ftructure, compared with the Urethra of the male fubject.

401. Of the Vagina.

Of the rugce, and nervous papilla of the vagina.

402. Of the Uterus.

Its fubftance, form, and fituation.

403. Of the os internum, cervix, and fundus uteri.

Of the ligaments of the uterus.

404. Of its blood veffels, \&c.

405. Of the Tuba fallopiance.

Their fituation, and connexion with the ovaria.

406. Of the Ovaria.

Their ftructure, fituation, \&c.

407. Of the Ovula and Corpora lutea.

408. Of the particular functions, and combined ufes of the above parts. 


\section{$(64)$}

409. Of the Menfes.

Of the caufe of the mentrual flux.

Of its natural duration and periodical return.

Confequences of the irregularity, obftruction, or excefs of this evacuation.

410. Of the diforders incident to women at the firt appearance, and natural ceffation of this difcharge.

411. Remarks on the caufe of periodical hæmorrhages.

412. Of droply of the ovarium.

413. Of the difeafes of the Uterus, \&c.

of Impregnation and Conception.

414. Of the ftate of the Uterus after conception. 






\section{( 65$)$}

\section{Of falfe conceptions.}

Obfervations on the production of monfters.

415. Of extra-uterine conceptions.

Of the Fatus in Utero.

416. Of the Placenta.

Its Aructure and fituation.

Of its connexion with the Uterus.

417. Of the umbilical cord.

418. Of the velfels which compofe it, and their peculiarities.

419. Of the Chorion and Amnios.

420. Of the Liquor Amnii.

421. *Of the Allantois.

422. Remarks on the mode of communication between the mother and the fœtus.

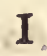

423. Of

- See comparative anatomy. 


\section{$(66)$}

423. Of the manner in which it is fupplied with nourifhment.

Various opinions of authors on this fubject.

424. Of the progreflive changes which the fotus undergoes, during the ufual terim of pregnancy.

425. Of the fituation of the foetus in utero at different periods of geftation.

26. Particular defcription of the circulation of the blood in a foetus.

of the ductus arteriofus, ductus venofus, \&c.

427. Of Parturition.

Symptoms of approaching labour.

428. Obfervations on the ufual modes of delivery. 






\section{$(67)$}

Of the extraction of the fecundines.

429. Of the caufes of difficult labour.

430. Symptoms of the child's being dead, \&c.

431. Of preternatural births, and the inftruments employed for the extraction of the foetus.

432. Of the Coefarean operation.

433. Of the difeafes incident to women during pregnancy.

434. Of the breafts, and the changes which take place in them during geftation, and after child birth.

435. Of the diforders fubfequent to parturition, \&c.

436. Of Abortion.

Its caufes and prevention.

437. Experiments generally inftituted (in fufpicious cafes) to afcertain, 


\section{(68)}

whether the child has been fill born, or the contrary.

438. Obfervations on the ufual appearances in cafes of fufpected violence.

439. Cautions to perfons who may be called upon to give evidence on fuch occafions. 






\section{(69)}

\section{Of the EAR.}

440. Of the external parts of the ear, and its mufcles.

Of the Meatus auditorius externus.

441. Of the Glandula Ceruminofa.

442. Of the Membrana Tympani.

Its ftructure, fituation, attachments, \&c.

443. Of the Offrcula Auditus, and the fmall muicles attached to them.

444. Of the Labyrinth of the ear.

445. Vefibulum, femicircular canals, and cochlea.

Of the two Feneftrce.

Of the mattoid cells, \&c.

446. Of the Tuba Euftachiana,

447. Of the auditory nerves, and their diftribution. 


\section{(70)}

Of the Chorda Tympani.

448. Of the feparate and combined ufes of all thefe parts.

449. Of the fenfe of hearing.

$45^{\circ}$. Of deafnefs, and its caufes.

451. Remarks on the cure of nervous deafnefs, by electricity:

452. Of pain in the ear, and other difeafes of that organ.

\section{Of the NOSE.}

453. Of the external parts of the nofe.

Of the bones of the nofe.

Of its mufcles and cartilages.

454. Of the Septum Narium.

455. Remarks on the peculiar form, fituation, and ufe of the of $\sqrt{a}$ Jpongiofa.

456. Of 






\section{( 71$)$}

456. Of the pofterior openings of the nofe.

457. Defcription of the finus's which communicate with its internal cavity, and their ufes.

458. Of the lachrymal fac.

459. Of the Membrana Schneideriana; or Pituitaria.

Structure, and extent of this membrane.

Of the mucus fecreted on its furface.

Remarks on the ufes of the pituitary membrane.

460. Of the olfactory nerves.

Their paffage through the cribtiform lamella of the xthmoid

- bone, and diftribution of them over the pituitary membrane.

461 . Of the fenfe of fmelling.

462. Of nafal hæmorrhages, Ozcena, Polypus, \&c. 


\section{$(72)$}

\section{Of the EYE.}

463. Of the external parts of the eye.

Of the Aructure and ufe of the eye-brows.

Of the eye-lids, \&c.

464. Of the lachrymal gland, and its excretories.

465. Structure and ufes of the punctd lachrymalia, caruncula lachrymalis, and lachrymal duct.

Of the Globe of the Eye.

466. Of the Tunica conjunctiva, or adnata.

Of the Tunica albuginea.

467 . Of the fix mufcles fubfervient to the eye.

Explanation of their fructure, fituation, and action.

Remarks 






\section{$(73 i)$}

Remarks on the uniform motion of the eyes.

Of the three proper coats of the eye.

468. General explanation of the manner in which the coats of the eye are formed.

${ }_{469}^{6}$. Of the Sclerotica and Cornea.

Particular examination of the ftructure and ufes of this coat.

Of its connexion with the Choroides.

470. Of the Choroides and Uvea or Iris.

Peculiarities of this coat:

471. Of the manner in which the Uvea is formed.

472. Of the Ligamentum Ciliare.

473. Of the Pigmentum nigrum.

474. Of the Pupil.

$$
\mathrm{K} \quad * \mathrm{Re}-
$$




\section{(74)}

*Remarks on the variety of its fructure in different animals.

475. Of the expanfion and contraction of the pupil.

Several phœnomena hence accounted for.

476. Of the Retina and Optic Nerve.

477. The entrance of the optic nerve into the orbit, defcribed.

The opinions concerning the manner in which the optic nerves are conjoined.

478. Of the ftructure and diftribution of the Retina.

\section{Of the three humours of the eye.}

479. General remarks on the fituation, tranfparency, \&c. of thefe humours.

480. Of the Chambers of the eye.

481. Of the Aqueous. Humour. 






\section{$(75)$}

Of its different degrees of tranfparency, at different periods. Remarks on the effect of the Jaundice upon this humour.

482 . Of the evaporation of the aqueous humour; and the regeneration of it after it has been artificially evacuated.

483. Pathological remarks on the caufe of Hydropthalmia.

484. Of the Cryftalline Humour.

of the ftructure and fituation of the Cryftalline Lens, and its Capfule.

485. Of its Shape and denfity.

Obfervations on its want of vifible attachment, \&c.

Different fates of it at different periods of life.

486. Of the Vitreous Humour.

Remarks on the quantity, and denfity of this humour.

$$
\begin{array}{ll}
\mathrm{K}_{2} & 487 . \mathrm{Of}
\end{array}
$$




\section{(76.)}

487 . Of the cellular ftructure of the membrane which contains it.

Of the cavity for the lodgement of the cryftalline, \&c.

\section{Of VIS I O N.}

488. Of the refracting powers, \&c. of the different humours of the eye.

489. Of the refpective ufes of the three coats of the eye.

490. Obfervations on the ufe of the ligamentum ciliare.

491. Of the change produced in the eye, that objects may appear diftinct at different diftances.

492. Of the manner in which the pictures of objects are formed upon the Retina.

493. Of the punctum coecum, and MARIOTTE'S experiment to prove the infenfibility of the Retina at that part. 






\section{( 77 )}

494. Difpute betwixt Mariotte and PEQueT concerning the feat of vifion.

495. Of the caufes and effects of the contraction and dilatation of the pupil.

Why we fee beft from a dark place to a light one, and vice verfa.

496. Obfervations on the ufe of the pigmentum nigrum.

Why fome people fee better in the dark than others, \&c.

Several other phœnomena accounted for.

497. Remarks on the caufe of Myopia, or fhort fight.

498. Of Prefbyopia, or weak fight.

Obfervations on the ufe of glaffes to remedy the above imperfections.

499. Of Cataract. 


\section{( 78 )}

Of couching, and the manner of performing that operation.

500. Of the various caufes of fquinting, and its ufual remedies.

501. Of other difeafes of the eye, and the methods of treating them.

Of the TEGUMENTJ of the Body.

502. Of the Cuticula or Epidermis.

Its fructure and office.

Of its fpeedy regeneration.

503. Remarks on the operation of blifters.

504. Of the rete mucofim.

Its fituation and uife.

505. Obfervations on the caufe of the black colour of Negroes, \&c.

506. Of the Cutis or Skin.

Its fructure in general.

507 . Of the papillæ of the fkin, 508. Ge- 






\section{$((79)$}

508. General remarks on the fenfe of FeELing.

509. Of infenfible tranfpiration.

510. Of the glandulce miliares.

511. Of the perfpirable matter.

Of its fecretion, paffage, and efcape from the body.

512. Of the quantity of this evacuation.

Experiments of SANCTORIUS, and others.

513. Of the cutaneous Lymphatics and of abforption from the furface of the fkin.

514. Obfervations on the ufe of nutritive baths.

515. Of the Membrana adipofa, and reticular fubftance.

Their texture and ufes.

516. An enquiry into the nature and ufe of fat.

517. Obfervations on the treatment of Emphyfema. 


\section{$(80)$}

518. Of the Nails.

Their Aructure, ufe, \&c.

519. Of the Hairs.

Manner of their growth and receiving nourifhment.

Of their general utility.

520. Of the alopecia, and plica polo. nica.

521 . Obfervations on the collections of hair found in the ftomachs of animals, and in fome abfceffes, $\& c$.

522. Of the fuppofed integuments of the antients:

523. Recapitulation of the principal phœnomena of the animal oconomy, which have been taken notice of in the preceding lectures.

Conclusion. 






\section{$(81)$}

\section{COMPARATIVE ANATOMY.}

\section{INTRODUCTION.}

1. OF the utility of comparing the fructure of man with that of animals.

Of the ufe of comparative anatomy in reading antient authors, and its importance in the ftudy of Zoology, \&c.

2. Obfervations on the comparative fize and ftrength of animals.

3. Of the general analogy obfervable in the ftructure of animals.

4. Of the divifion of animals into claffes.

$$
\text { L }
$$




\section{$(82)$}

5. Of Quadrupeds.

6. Remarks on the peculiarities in the fkeletons of different quadrupeds.

7. Obfervations on the ftructure, and ufes of the tails of various animals.

8. Of the Panniculus Carnofus.

9. Of the fituation of the heart compared with that of the fame organ in the human fpecies.

10. Of the brain and nerves of quadrupeds.

11. Of the rete mirabile, or plexus of blood veffels on each fide of the fella turcica.

Reflections on the ufe of this plexus.

12. Of the Nose of quadrupeds.

Of its internal ftructure, and of the paffage, and diftribution of the olfactory nerves. 






\section{$(83)$}

Remarks on the caufe of the acute fenfe of fmelling in various animals.

13. Of the Ears.

Of the variety in the fhape, fituation and ufes of the external ear.

14. Of the Eye.

Its ftructure in different animals.

Of the mufculus fuppenforius.

15. Of the membrana nictitans.

16. Of the figure of the pupil in dif-: ferent animals.

Of its extreme dilatability in fome animals, as in the cat, \&c.

17. Of the different colours of the choroid coat, or Tapetum, in different animals.

Why certain animals are ena- bled to fee with very little light.

$$
\mathrm{L}_{2}
$$




\section{$(84)$}

18. Of the fructure of the Teвtr in various animals.

Of the difference between the teeth of granivorous, and thofe of carnivorous animals.

19. Of the want of the Uvula in qua, drupeds, and the ufe of the mufcle attached to the Glottis.

\section{Anatomy of a Dog.}

20. Of the Omentum.

Remarks on the fize and extent of the omentum in quadrupeds.

21. Of the chylopoietic vifcera.

Of the longitudinal direction of . the valvula conniventes.

Structure of the inteltines of this animal compared with that of the human inteftines.

22. Of the digeftion of carnivorous animals. 






\section{$(85)$}

Remarks on the fize of the Ap. pendix Vermiformis.

Of the Pancreas Afellii.

Of the bags found at the extremity of the rectum.

23. Of the pancreas, spleen, and liver of this animal.

24. The kidneys and urinary bladder, compared with the fame parts in the human fubject.

25. The openings in the abdomen for the paffage of the teftes to the fcrotum, compared with the abdominal rings in men.

26. Of the male parts of generation.

Of the want of veficula feminales in the dog.

Remarks on the tedious copulation of this animal.

27. Of the female parts of genera. tion. 


\section{( 86$)$}

28. Of the defect of fenfible perfpiration in this fpecies.

29. Remarks on the caufe and prevention of the Rabies canina,

Of the Hydrophobia and the attempts to cure this difeafe.

30 . Of the peculiarities obfervable in the anatomy of a Horse.

31. Of the courfe of the principal blood veffels, \&c.

32. Remarks on fome of the mot common difeafes of horfes.

\section{Of Ruminant Animals.}

33. *Of the four ftomachs of ruminant animals, compared with the fingle ftomach of other quadrupeds.

Of

- All ruminant animals have more than one ftomach. 






\section{( 87$)$}

Of the manner in which rumina. tion is performed.

Why ruminant animals require lefs food than other granivorous quadrupeds, who have but one ftomach.

34. Of the parts of generation of a cow.

Of the Uterus and its Cormua.

35. Of the Fotus.

36. Of the Urachus and Allantois, or refervoir of urine peculiar to the fotus of quadrupeds.

\section{Or Birds.}

37. General remarks on this clafs of animals.

38. Of the peculiarities in the Ikeletons of birds.

39. Of the ftomach and inteftines of the carnivorous, compared with thofe of granivorous birds. 


\section{( 88 )}

40. Of the fuccus gaftricus, and the digeftive faculties of the carnivorous tribe.

42. Of the ventriculus fuccenturiatus, and gizzard.

43. Of the triturating power of the gizzard, and the manner in which their food is digefted.

44. Of the abforbent fyftem in birds.

45. Of the kidneys and paffage of the urinary fecretion.

46. Of the extent and attachment of the lungs.

Of their communication with the abdominal veficles, and the air cells in the bones of thefe animals.

47. Of the Diaphragm.

48. Of the brain compared with that of quadrupeds.

49. Of the olfactory nerves, and the organ of fmelling. 






\section{( 89 )}

50. Of the eye, and its peculiarities in this clafs of animals.

Of the Marfupium nigrum, or Bourfe noire.

$5^{1}$. Of the organ of hearing in birds.

52. Of the organs of generation in the male.

53. Of the organs of generation in the female.

Of the vitellarium, infundibulum, \&c.

54. Of the phœnomena attending the paffage of the egg to the uterus.

55. Structure of an egg explained.

56. Of the progreffive changes which the egg undergoes during incubation.

Of the nourifhment of the fœtus of oviparous animals.

M

57. Of 


\section{( 90$)$}

57. * Of the fecretion in the crops of breeding pidgeons for the nourifhment of their young.

In Of Amphibious Animals.

58. Of the heart and lungs of amphibia.

Of the peculiarities in the fructure of thefe organs.

59. Of the tranfverfe canals in the feptum between the ventricles, exemplified in the heart of a turtle.

\section{Of the ufe of thefe canals.}

60 . Why all the arteries proceed from the right ventricle.

61. Defcription of the circulation of the blood in this clafs of animals.

\section{2. $\mathrm{Ob}-$}

* See a Differtation on this fubject, and alfo an account of the Air Cells in the Bones of Birds; in Obfervations on certain parts of the Animal CEconomy, lately publined by Mr. J. Hunter. 



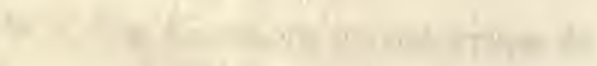
$1+2$

$\sqrt{2}+x^{2}$
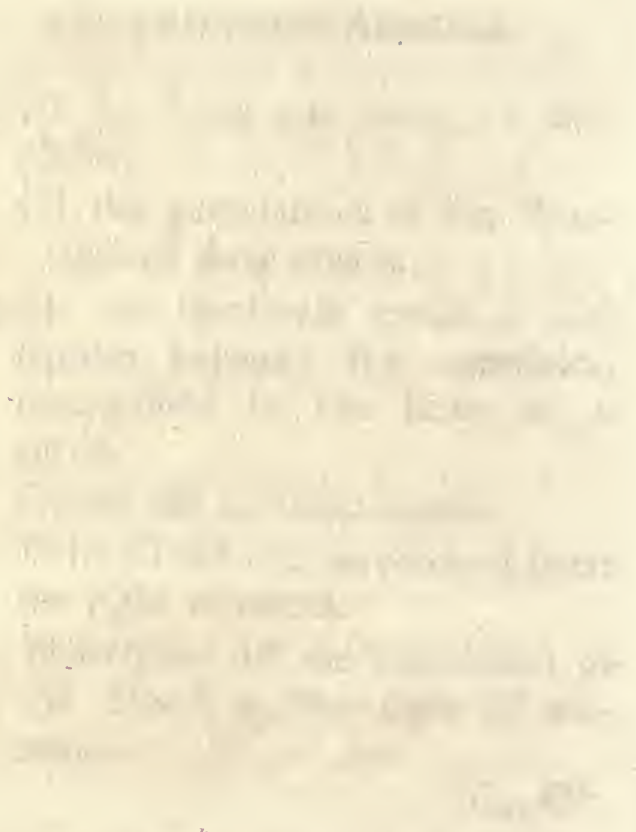

(n) (1) 




\section{( $\left.9^{1}\right)$}

62. Obfervations on the pulmo arbitrarius enjoyed by them.

63. General remarks on the ftructure of ferpents.

64. Of the teeth of ferpents, and their canal for the paffage of the poifonous fluid.

Of the refervoir in which this fluid is contained.

65. Of the general effects of wounds made by the teeth of venomous ferpents.

66. Obfervations on the treatment of perfons bit by this fpecies of animals.

\section{OF Fishes.}

67. Remarks on the ftructure and ufe of the fins, tail, and other external parts.

68. Of the fituation, and Atructure of the teeth of fifhes?

$$
\mathrm{M}_{2} \quad 6 g \text {. Of }
$$




\section{( 92$)$}

69. Of the organs of digeftion, and of the chylopoietic canal.

70. Of the fwimming bladder and its ufe.

71. Of the fize and Aructure of the liver.

Of the fituation of the gall bladder, and courfe of the hepatic and cyftic ducts, \&c.

72. Of the intefinula coca, and their terminations.

73. Of the fpleen, \&c.

74. Defcription of the heart, and its veffels.

Of the fingle form of the heart, being compofed of one auricle and one ventricle.

75. * Of the circulation of the blood in this clafs of animals.

* See a Treatife on the Strueture and Phyfiology of Fifhes, publifhed in 1785 , by Alex. Monro, M. D. Profeffor of Phyfic, Anatomy, and Surgery, in the Univerfity of Edinburgh. 


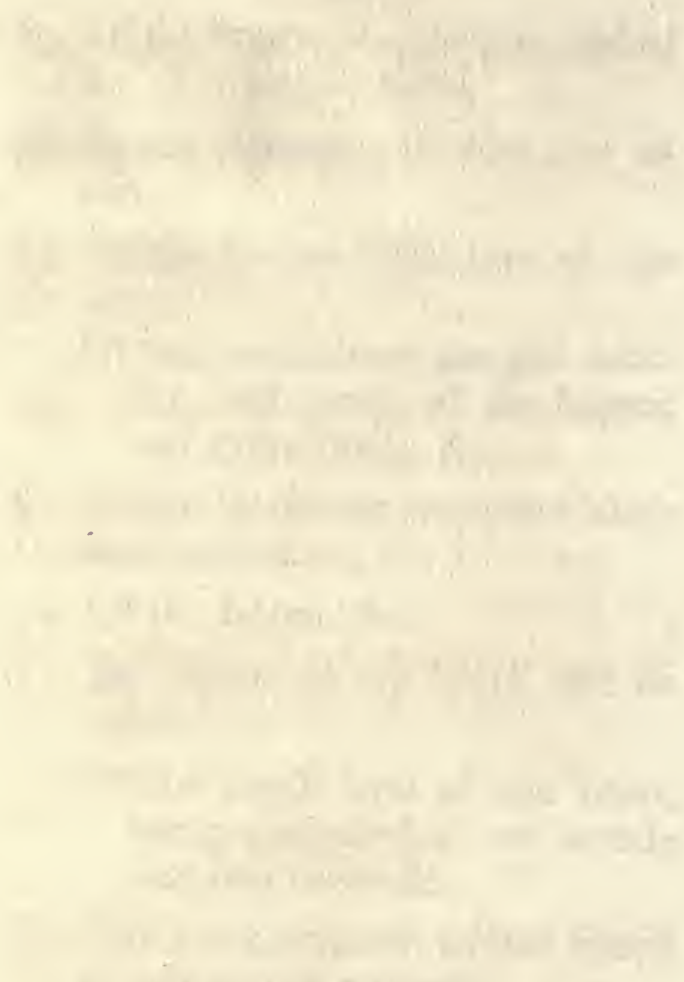

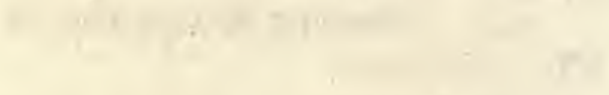






\section{(93)}

Of the paffage of the blood from the ventricle of the heart to the gills, by the bronchial artery:

Of the union of the bronchial veins forming trunks, which perform the office of arteries, and convey the blood, (by their ramifications) all over the body.

Of the return of the blood to the heart by the Vence cavae.

76. Remarks on this mode of circulation, and on the ufe of the gills.

Obfervations on the peculiarities of the circulation in the Sepia Loligo, or cuttle filh.

77. Of the abforbent fyftem in filhes.

78. Of the Brain and Nerves.

79. Of the organ of fmell in fifhes.

80. Of the Ear. 


\section{( 94 )}

81. Its fructure and fituation in the cartilaginous and offeous fifhes.

82. Obfervations on the faculty of hearing in water.

83. Of the eye.

Peculiarities of the cryftalline, \&c.

84. Of the mucus ducts, and the fecretion of the liquor for the lubrication of the external furface of filhes.

85. Of the parts of generation in the cartilaginous and offeous fifhes.

86. Of Infects, Vermes, \&c.

Conclusion. 






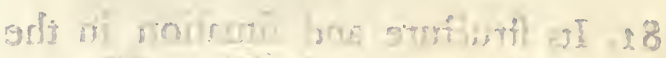

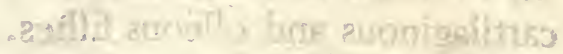

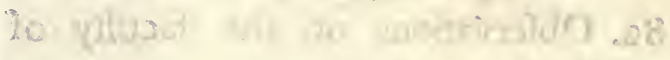

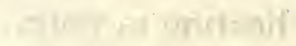

andille:

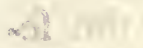

$=y^{k}=-4+2$.

20 hit:-it

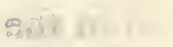




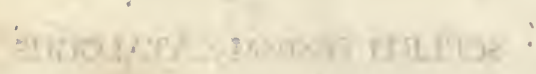




\section{SCELETI OSSIUM CATAIOGUS.}

-OS Frontis.

Os Parietale

Os Temporale

- Os Occipitis

* Os Ethmoidale

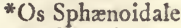

Os Unguis

Os Nafi

Os Malre

Os Maxillare

Os Spongiofum inferius

Os Palati

*Vomer

* Maxilla inferior

Dentes $\left\{\begin{array}{l}\text { Incifores } \\ \text { Canini } \\ \text { Molares }\end{array}\right.$

*Os Hyoides

Officula $\left\{\begin{array}{l}\text { Stapes } \\ \text { Incus } \\ \text { Malleus } \\ \text { Os Orbiculare }\end{array}\right.$

Cofta $\left\{\begin{array}{l}\text { Veræ feptem. } \\ \text { Spuriæ quinque }\end{array}\right.$

* Sternum

Clavicula

Scapula

Os Humeri

Ulna

Radius

Offa Metacarpi

Offa Digitorum quindecim

$\mathrm{O}_{3}$ Femoris

Tibia

Fibula

Patella

*Vertebræ $\left\{\begin{array}{l}\text { Colli feptem } \\ \text { Dorfi duodecim } \\ \text { Lumborum quinq. Offa Tarfi }\end{array}\left\{\begin{array}{l}\text { Aftragalus } \\ \text { Os Calcis } \\ \text { Os Navicularé } \\ \text { Offa Cuneiformia } \\ \text { Os Cuboides }\end{array}\right.\right.$

Illio Ofra Metatarfi quinque Os Innominatum ex $\left\{\begin{array}{l}\text { Ifchio Offa Digitorum Pedis quatuor- } \\ \text { Pube }\end{array}\right.$ Lunare

Cuneiforme

Offis Carpi $\{$ Pififorme Trapezium

Trapezoides

Magnum

Unciforme

MUS.

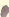

Thofe bones which are fingle in the fkeleton, have no afterifk before them, - the reft are in pairs. 


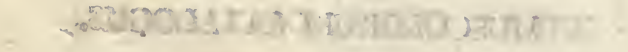

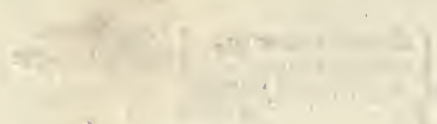

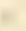
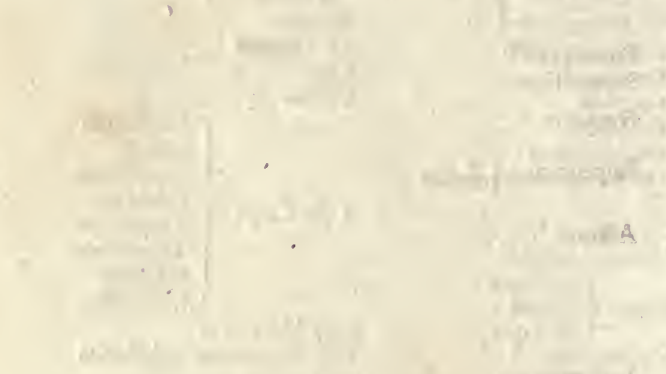

wher the

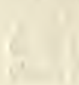

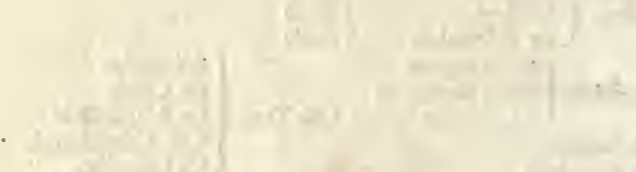

-

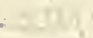

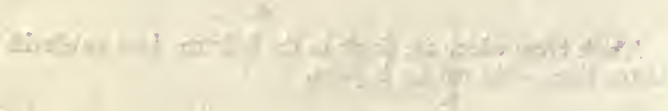
$+$ 




\section{MUSCULORUM CATALOGUS.}

Abdominis $\left\{\begin{array}{l}\text { Obliquus externus. } \\ \text { Obliquus internus. } \\ \text { Tranfverfalis. } \\ \text { Rectus. } \\ \text { Pyramidalis. }\end{array}\right.$

Frontis et Occipitis. Occipito-Frontalis.

Superciliorum. Corrugator.

Genarum $\{$ Quadratus, five Platyfma Myoides.

Palpebrarum $\left\{\begin{array}{l}\text { Orbicularis. } \\ \text { Aperiens Rectus }\end{array}\right.$

Alarum Nafi $\left\{\begin{array}{l}\text { Levator. } \\ \text { Dilator. } \\ \text { Conftrictor five Tranfverfalis。 }\end{array}\right.$

Labiorum $\left\{\begin{array}{l}\text { Elevator } \\ \text { Depreffor } \\ \text { Elevator } \\ \text { Depreffor } \\ \text { Elevator } \\ \text { Depreffor } \\ \text { Zygomaticus major, et minor. } \\ \text { Orbicularis. }\end{array}\right.$

Auriculam $\left\{\begin{array}{l}\text { Attollens. } \\ \text { Retrahens. }\end{array}\right.$

Obliquus $\left\{\begin{array}{l}\text { Superior, five Trochlearisi } \\ \text { Inferior. }\end{array}\right.$

Oculorim $\left\{\begin{array}{l}\text { Attollêns. } \\ \text { Deprimens. }\end{array}\right.$

Abductor.

Adductor.

Aaris Internæ $\left\{\begin{array}{l}\text { Externus: } \\ \text { Internus. } \\ \text { Obliquus. } \\ \text { Stapedæus. }\end{array}\right.$

Offis Hyoidis $\left\{\begin{array}{l}\text { Sterno-hyoidæus: } \\ \text { Coraco-hyoidæus. } \\ \text { Stylo-hyoidæus: } \\ \text { Genio-hyoidæus. } \\ \text { Milo-hyoidæus. }\end{array}\right.$ 


\section{( iv)}

Linguæ $\left\{\begin{array}{l}\text { Genio-gloffus. } \\ \text { Stylo-gloffus. } \\ \text { Bafio-chondro- }\end{array}\right.$

Bafio-chondro-cerato Gloffus.

Linguales.

Uvula $\left\{\begin{array}{l}\text { Glofio-Staphylinus. } \\ \text { Pterigo-Staphylinus. } \\ \text { Pharyngo-Staphylinus. }\end{array}\right.$

Pharyngxus.

Levator, five Salpingo-Staphylinus.

Oefophagæus.

Laryngis $\left\{\begin{array}{l}\text { Sterng-thyroidæus. } \\ \text { Hyo-thyroidæus. } \\ \text { Crico-thyroidæus. } \\ \text { Crico-Arytenoidæus \{pofticus. } \\ \text { Arytenoidæus major, et minor. }\end{array}\right.$

Thyro:Arytenoidaus.

Maxilla Inferioris $\left\{\begin{array}{l}\text { Tenporalis. } \\ \text { Mafleter. }\end{array}\right.$

2. Pterigoidaus externus, et internus.

Serratas Anticus major, et minor.

Subclavius.

Scalenus.

Thoracis $\left\{\begin{array}{l}\text { Triangularis Sterni. } \\ \text { Tealents }\end{array}\right.$

DIAPHRAGMA.

Intercoftales externi, et interni.

-Serratus Pofticus fuperior, et inferior.

Scapula $\left\{\begin{array}{l}\text { Trapezius, five Cucullaris. } \\ \text { Rhomboides. } \\ \text { Levator, five Mufculus Patientix. }\end{array}\right.$

Splenius.

Complexus.

Rectus Pofterior, major, et minor.

Obliquus fuperior, et inferior.

Capitis $\{$ Sterno-maftoidæus.

Trachelo-maftoidæus.

Rectus Anterior $\left\{\begin{array}{l}\text { major. } \\ \text { minor. } \\ \text { lateralis. }\end{array}\right.$

Longus.

Spinalis.

Colli Semifpinalis.

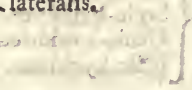

Tranfverfalis.

Inter-fpinales.

Inter-tranfverfales. 




Dorfi $\left\{\begin{array}{l}\text { Sacrolumbalis. } \\ \text { Longifimus. }\end{array}\right.$

Lumborum $\left\{\begin{array}{l}\text { Quadratus. } \\ \text { Sacer. } \\ \text { Pfoas Parvus. }\end{array}\right.$

Coccygxus.

$\begin{aligned} \text { Humeri } & \left\{\begin{array}{l}\text { Pectoralis. } \\ \text { Deltoides. } \\ \text { Supra-fpinatus. } \\ \text { Infra-fpinatus. } \\ \text { Teres minor, et major. } \\ \text { Latifimus Dorfi. } \\ \text { Coraco brachialis. } \\ \text { Subfcapularis. }\end{array}\right. \\ \text { Humeri } & \begin{array}{l}\text { Biceps Flexor. } \\ \text { Brachiæus internus. } \\ \text { Biceps extenfor, five Gemellus. } \\ \text { Brachiaus externus. } \\ \text { Anconæus. }\end{array}\end{aligned}$

Volæ Manus. Palmarus longus, et brevis.

Radii $\left\{\begin{array}{l}\text { Supinator longus, et brevis. } \\ \text { Pronator Teres, et quadratus. }\end{array}\right.$

Carpi $\{$ Flexor, Radialis, et Ulnaris.

Carpi \{Extenfor, Radialis, et Ulnaris.

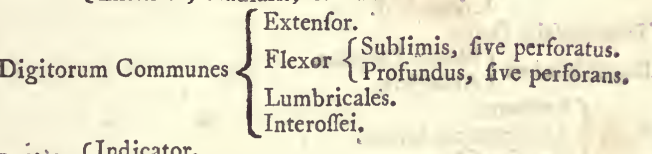

Indicis $\left\{\begin{array}{l}\text { Indicator. } \\ \text { Adductor proprius, et communis. }\end{array}\right.$

Digiti minimi $\left\{\begin{array}{l}\text { Abductor. } \\ \text { Primi internodii flexor. } \\ \text { Extenfor. }\end{array}\right.$

Pollicis $\left\{\begin{array}{l}\text { Flexor internodii primi, fecundi, et tertii five Iongus. } \\ \text { Extenfor internodii primi, fecundi, et tertii. } \\ \text { Abductor. }\end{array}\right.$ Abductor.

Adductor, proprius et communis.

Flexor Offis Metacarpi, minimum Digitum fuftinentis.

Femoris $\left\{\begin{array}{l}\text { Pfoas magnus. } \\ \text { Iliacus internus. } \\ \text { Pectineus. } \\ \text { Glutæus magnus, medius et minimus, } \\ \text { Triceps Extenfor. } \\ \text { Iliacus Externus, five pyriformis. } \\ \text { Gemelli. } \\ \text { Obturator externus, et internus five Marfupialis. } \\ \text { Quadratus. }\end{array}\right.$ 


\section{( vi )}

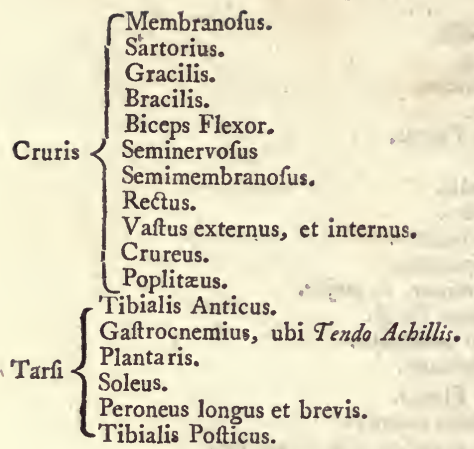 Digitorum Pedis $\left\{\begin{array}{l}\text { Extenfor longus, et brevis. } \\ \text { Flexor Perforatus, et Perforans. }\end{array}\right.$ Lumbricales. Interoffei.

Pollicis Pedis $\left\{\begin{array}{l}\text { Extenfor longus, et brevis. } \\ \text { Flexor longus, et brevis. } \\ \text { Abductor. } \\ \text { Adductor. }\end{array}\right.$

Tranfverfalis Pedis.

Digiti Minimi $\left\{\begin{array}{l}\text { Flexor Proprius. } \\ \text { Abductor. }\end{array}\right.$

Penis $\left\{\begin{array}{l}\text { Erectores. } \\ \text { Acceleratores Urinæ. } \\ \text { Tranfverfalis. }\end{array}\right.$

Clitoridis, Erector.

Vaginæ Sphincter.

Ani $\left\{\begin{array}{l}\text { Levatores. } \\ \text { Sphincter. }\end{array}\right.$

\section{$F I N I S$.}







\section{UNIVERSITY OF CALIFORNIA LIBRARY}

Los Angeles

This book is DUE on the last date stamped below.

RECO [D.URE

\section{Hov 181980}



